\title{
Production Process Effect on Mexican Agave Syrups Quality: A Preliminary Study
}

\author{
Blanca I. Maldonado-Guevara ${ }^{1}$, Sandra T. Martín del Campo ${ }^{1}$, \& Anaberta Cardador-Martínez ${ }^{1}$ \\ ${ }^{1}$ Escuela de Ingeniería y Ciencias, Tecnologico de Monterrey, Campus Querétaro. Querétaro, Querétaro, México \\ Correspondence: Anaberta Cardador-Martínez, Epigmenio González No.500, Fraccionamiento San Pablo, \\ C.P.76130, Querétaro, Querétaro, México. Tel: 52-442-238-3224. E-mail: mcardador@itesm.mx
}

Received: February 14, 2018

Accepted: March 2, 2018 Online Published: March 30, 2018

doi:10.5539/jfr.v7n3p50

URL: https://doi.org/10.5539/jfr.v7n3p50

\begin{abstract}
In this work, the quality parameters of commercial agave syrups produced in five different Mexican states and with different production process were evaluated. Regulated parameters ( $\mathrm{pH}$, Moisture, Ashes, and 5-(hydroxymethyl) furfural), as well as color and $\mathrm{a}_{\mathrm{w}}$, were measured on 25 agave syrups, including traditional samples as controls. Traditional and semi-industrial syrups were samples obtained by thermal hydrolysis. Additionally, the semi-industrial process included control of process variables such as $\mathrm{pH},{ }^{\circ} \mathrm{Bx}$, and temperature. The industrial process is technified. The agave syrups ranged from $70-76{ }^{\circ} \mathrm{Bx}, \mathrm{pH}$ ranged from $3.2-6.7$, and moisture from $20.2-28.6 \%$. The $\mathrm{a}_{\mathrm{w}}$ values shown a wide variation as well as $\mathrm{L}^{*} \mathrm{a}^{*}$ and $\mathrm{b}^{*}$ color parameters. Some of those parameters shown significant differences in ANOVA analysis; however, most of the samples complied with the norm. General Discriminant Analysis (GDA) made it possible to discriminate between production process by using $\mathrm{pH}, \% \mathrm{Ash}, \mathrm{b}^{*}, 5$-(hydroxymethyl)furfural and $\mathrm{a}^{*}$ parameters. Further analysis of a wide range of syrups and the inclusion of non-regulated compounds such as volatile compounds and carbohydrates are needed to get more information for a deeper characterization of agave syrups.
\end{abstract}

Keywords: agave syrup, food regulation, general discriminant analysis, physicochemical properties, production process

\section{Introduction}

Agave plants accumulate in its stems nonstructural carbohydrate that has been used to produce alcoholic beverages like tequila, mezcal, and bacanora (Rendón-Salcido, Magdub-Méndez, Hernández-Terrones, \& Larqué-Saavedra, 2007). Those carbohydrates are also used for syrup and sap production, which were the unique sweeteners available from nature to the natives during pre-Hispanic times (Montañez Soto, Venegas González, Bernardino Nicanor, \& Ramos Ramírez, 2011). Agave syrup and sap were used for cooking, preserving foods, and for treating many diseases; for instance: diabetes, arthritis and cardiovascular, and also as a scarring promoter and anticancer agent (García-Pedraza et al., 2009; Gutierrez-Uribe \& Serna-Saldivar, 2013; Santos-Zea, Maria Leal-Diaz, Cortes-Ceballos, \& Alejandra Gutierrez-Uribe, 2012).

Agave syrup is produced by three different processes (Fig. 1): Traditional (A) which consist on heating the sap in pots placed on the fire to hydrolyze carbohydrates and kept there until water evaporation. Empirical knowledge is mainly used for the control of the process. The traditional process is currently done as described by Spanish chroniclers (Pardo, 2007). Semi-industrial process (S) uses the thermal hydrolysis of sap, but only a few variables are controlled, for instance: $\mathrm{pH},{ }^{\circ} \mathrm{Bx}$, and temperature; suggesting the use of basic quality control practices. Industrial (I) is the most sophisticated process of production and involves the use of the whole agave pine (raw or semi-cooked), the careful control of the process variables and also the use of more sophisticated technology for carbohydrate extraction and its subsequent hydrolysis. The main methods of carbohydrates industrial hydrolysis are: enzymatic, acid (García-Aguirre et al., 2009; Willems \& Low, 2012) and the combination of them (García-Aguirre et al., 2009; Montañez-Soto, González-Hernández, Venegas-González, Bernardino Nicanor, \& González-Cruz, 2013).

Legislation (NOM-003-SAGARPA-2016, 2016) does not restrict the kind of agave that can be used as raw material. The most common agave species used for syrup production are A. tequilana, A americana, A. potatorum, A. salmiana and A. atrovirens (Rendón-Salcido et al., 2007; Santos-Zea et al., 2012). The variability of production methods, kind of agave, growing agave's region; and part of the plant used in the production 
process (sap, leaves or pine), generates a wide range of products sold under the name of agave syrup.

Fructose-rich syrups have received increased attention in recent years, becoming the most demanded sweeteners by the global food and pharmaceutical industries due to their functional and technological advantages over sucrose (García-Aguirre et al., 2009; Mellado-Mojica \& López, 2015; Montañez Soto et al., 2011) and also by their beneficial health effects (García-Aguirre et al., 2009), related with the presence of bioactive compounds such as amino acids and fructanes (Muñiz-Márquez et al., 2015), giving to it antioxidant capacity and antibacterial properties among others.

Mexican regulation NOM-003-SAGARPA-2016 (2016) establishes the food quality, authenticity, labeling and conformity assessment of agave syrup. Despite the existence of mandatory regulation, the characteristics and chemical composition of the products sold as agave syrup are wide, and there is no guarantee of the authenticity of the product. This study aims to evaluate the quality and the concordance with norms of commercial agave syrups.

\section{Materials and Methods}

\subsection{Agave Syrup Samples}

For this study, a total of 25 samples of agave syrup from six different states of México were analyzed. From them, 12 samples were from Jalisco $(\mathrm{J})$, one from Coahuila (C), four from Estado de México (E), one from Hidalgo $(\mathrm{H})$, six from Querétaro $(\mathrm{Q})$, and one from Nuevo León $(\mathrm{N})$. The samples were classified depending on its production process: 20 of the samples were Industrial (I), 3 were Semi-industrial (S), and 2 of the samples were Traditional or artisanal (A) (Figure 1). Traditional samples were included in the study as controls and were obtained from producers who guaranteed its inclusion in this category (process and raw material). Traditional samples were produced in Jalisco and Queretaro from A. tequilana Weber var. azul and A salmiana respectively.

All the samples were stored at $20 \pm 2{ }^{\circ} \mathrm{C}$. Before analysis, samples were homogenized manually.

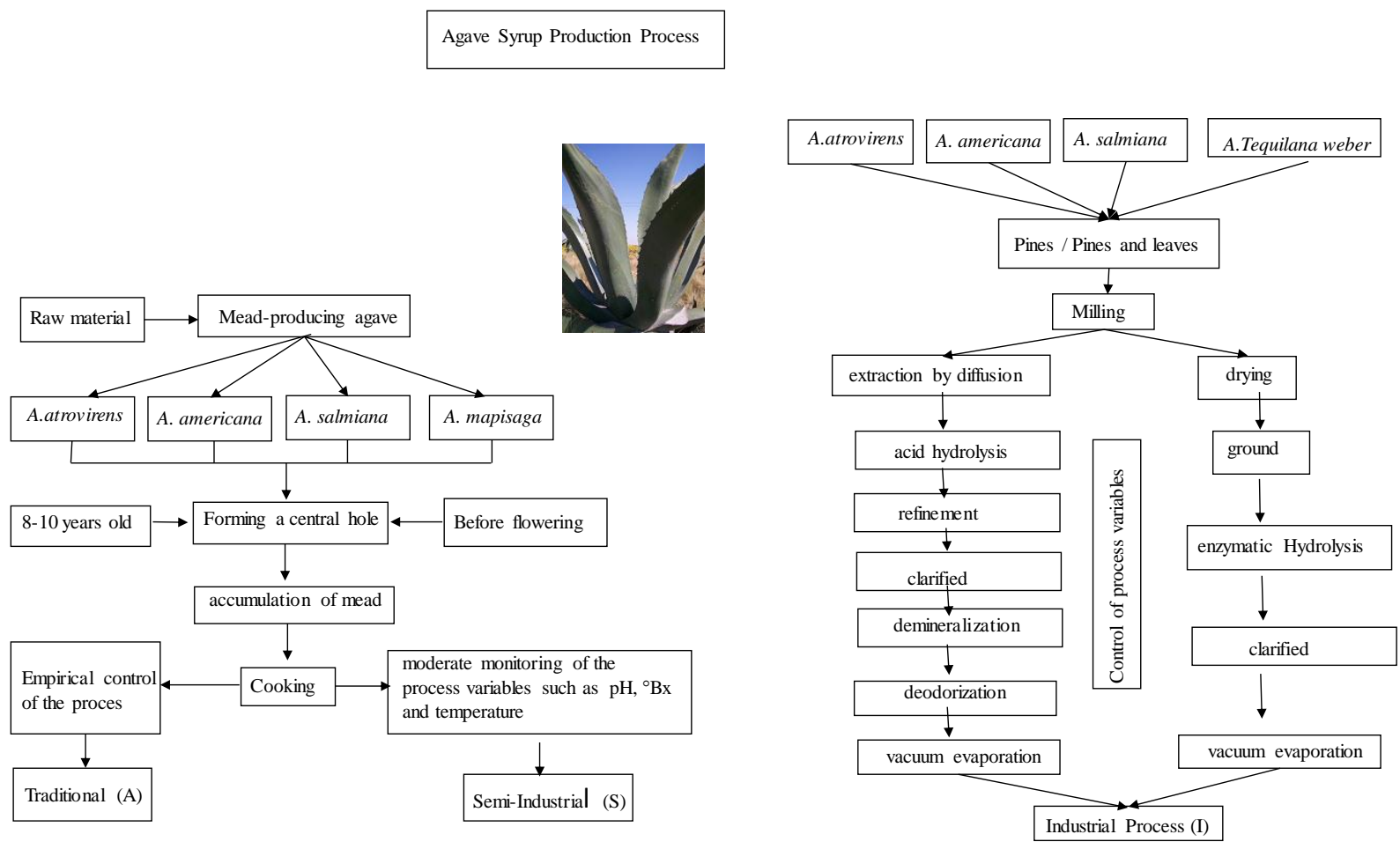

Figure 1. Diagrams of Traditional (A), Semi-industrial (S) and two examples of Industrial (I) production process of Agave Syrup

\subsection{Chemicals}

5-hydroxymethyl-2-furfuraldehyde (5-HMF) was purchased from Sigma-Aldrich Canada Ltd., Methanol, HPLC grade, was obtained from Karal (León, Guanajuato, México). The water used was obtained from a Millipore Milli-Q water system with a resistivity of $18.2 \mathrm{M} \Omega . \mathrm{cm}\left(25^{\circ} \mathrm{C}\right)$ and a Total Organic Carbon (TOC) lower than 5 
ppb (Millipore Corporation, Milford, MA, USA). Buffers pH 4 and 7 were obtained from Karal (León, Guanajuato, México).

\subsection{Regulated Physicochemical Parameters}

The regulated physicochemical parameters were evaluated according to the Mexican regulation NOM-003-SAGARPA-2016 (2016). Samples were analyzed by duplicate.

$\mathrm{pH}$ measurements were performed using an Oakton $510 \mathrm{pH}$ meter (Oakton Instruments, Vernon Hills, Il, USA), calibrated at $\mathrm{pH} 4$ and $\mathrm{pH} 7$ at $20 \pm 1{ }^{\circ} \mathrm{C}$, in a solution made with $10 \mathrm{~g}$ of agave syrup and $100 \mathrm{~mL}$ of distilled water.

Total soluble solids $\left({ }^{\circ} \mathrm{Bx}\right)$ and refractive index were obtained using an Abbé refractometer NAR-1T LIQUID (Atago Co., LTD, Minato-ku, Tokyo, Japan) at $20 \pm 1{ }^{\circ} \mathrm{C}$, on homogenized samples. Moisture content (\%M) was calculated according to the procedure in the Mexican regulation.

Ashes were quantified gravimetrically: 5-10 g of sample was placed in a porcelain crucible and then carbonized using a Bunsen burner; and placed on a muffle at $600 \pm 25^{\circ} \mathrm{C}$ until constant weight.

The content of 5-HMF was determined using a 1200 series HPLC, equipped with a quaternary pump, autosampler, diode array detector, degasser and thermostated column compartment (Agilent Technologies, Santa Clara, CA, United States). A Zorbax Eclipse XDB C18 column of 4.6 x $150 \mathrm{~mm}$ packed with $5 \mu \mathrm{m}$ particles size (Agilent Technologies) was used. A sample of $10 \mathrm{~g}$ was dissolved in MillyQ water until a volume of $50 \mathrm{~mL}$, and filtered using a $0.45 \mu \mathrm{m}$ PTFE filter, $13 \mathrm{~mm}$ diameter (Agilent Technologies). An aliquot of $20 \mu \mathrm{L}$ of the sample solution was injected using a $0.5 \mathrm{~mL} \mathrm{~min}^{-1}$ isocratic flow of methanol-water $(10: 90 \mathrm{v} / \mathrm{v})$. The detector was set at $285 \mathrm{~nm}$. Run was performed for 7 minutes. A calibration curve of $5-\mathrm{HMF}(0.00$ to $0.1 \mathrm{mg} / \mathrm{kg})$ was used, with a minimum $r^{2}$ of 0.98 .

\subsection{Color}

The agave syrup color was measured using a Minolta CM-5 spectrophotometer (Konica Minolta) standardized with both black and white standards on transmittance mode, using a Cell CM-A98 $(10 \mathrm{~mm})$, at $20 \pm 1{ }^{\circ} \mathrm{C}$. The color was reported as Hunter $L^{*}, a^{*}, b^{*}$ tristimulus values. All the samples were analyzed using a D65 illuminant.

\subsection{Water Activity}

Water activity $\left(\mathrm{a}_{\mathrm{w}}\right)$ was measured using an Aqualab dew point water activity meter 4TE, (Decagon devices, WA, USA), at $20 \pm 1{ }^{\circ} \mathrm{C}$, calibrated with a water activity standard of $6 \mathrm{~mol} \mathrm{~kg}^{-1} \mathrm{NaCl}\left(0.76 \mathrm{a}_{\mathrm{w}}\right)$.

\subsection{Statistical Analysis}

All the statistical analysis were carried out using the STATISTICA software 13.3 (TIBCO software INC). Full factorial ANOVA analysis was performed for all the physicochemical parameters analyzed by the state as well as by production process to identify significant differences $(\mathrm{p}<0.05)$. Additionally, the Fisher's least significant difference (LSD) test was performed for each significant physicochemical parameter for testing the population means to group the samples according to the evaluated factor. After that, a General Discriminant Analysis (GDA) was carried out to reduce the number of variables that made it possible to discriminate between samples; both, by state or production process. For both data sets forward stepwise analysis ( $\mathrm{p}$ inclusion 0.05 , p exclusion 0.05 ) was carried out to reduce the number factors for the discriminant model.

\section{Results and Discussion}

\subsection{Quality Parameters}

Results obtained for quality parameters of the analyzed samples are shown in Table $1 .{ }^{\circ} \mathrm{Bx}, \mathrm{pH}$, and $\% \mathrm{M}$ showed values outside the range; for instance, ${ }^{\circ} \mathrm{Bx}$ had lower $\left(70{ }^{\circ} \mathrm{Bx}\right)$, and $\% \mathrm{M}$ had a higher value $(28.6 \% \mathrm{M})$ than the norm parameter. The other regulated parameters presented values between the limits (NOM-003-SAGARPA-2016, 2016). Lower values on ${ }^{\circ} \mathrm{Bx}$ and higher $\% \mathrm{M}$ indicates a lower content of sugars than specified in the norm. A lower content of sugars could be associated with a higher susceptibility to microorganisms' growth. The obtained 'Bx values were lower than those reported by Willems and Low (2012) and in the range of the obtained by Mellado-Mojica and López (2015) with commercial syrups (74.61-77.47 and 65-76, respectively). 
Table 1. Quality Parameters of Agave Syrup Compared to the Official Mexican Regulation (NOM-003-SAGARPA-2016, 2016)

\begin{tabular}{llllll}
\hline Quality parameter $^{\pi}$ & \multicolumn{3}{c}{ Data Obtained $^{\&}$} & \multicolumn{2}{c}{ Specifications by Agave Syrup Norm } \\
\hline & Minimum & Maximum & Average & Minimum & Maximum \\
\hline RI & 1.465 & 1.490 & 1.48 & n.s. & n.s. \\
${ }^{\circ} \mathrm{Bx}$ & 70 & 76 & 74.6 & $71^{\$}$ & $79^{\$}$ \\
$\mathrm{a}_{\mathrm{w}}$ & 0.592 & 0.790 & 0.66 & n.s. & n.s. \\
$\mathrm{pH}$ & 3.2 & 6.7 & 4.6 & 4.0 & 6.0 \\
$\% \mathrm{M}$ & 20.2 & 28.6 & 23.35 & 20.0 & 28.0 \\
$\%$ Ash & 0.1 & 0.2 & 0.11 & 0.0 & 0.6 \\
$5-\mathrm{HMF}$ & 0.0 & 0.1 & 0.02 & 0.0 & 0.7 \\
$\mathrm{~L}^{*}$ & 0.21 & 100.00 & 62.43 & n.s. & n.s. \\
$\mathrm{a}^{*}$ & -3.42 & 48.01 & 15.8 & n.s. & n.s. \\
$\mathrm{b}^{*}$ & 0.20 & 100.00 & 52.78 & n.s. & n.s. \\
\hline
\end{tabular}

$\pi R I$ : Refractive Index; aw: Water activity, 5-HMF: 5-(hydroxymethyl)furfural (g/100 g)

\$The minimum and maximum values were obtained from all agave syrups analyzed.

\# n.s.: not specified in Mexican regulation.(NOM-003-SAGARPA-2016, 2016);

\$ Calculated as indicated in NOM-003-SAGARPA-2016 (2016).

Wide variability in $\mathrm{a}_{\mathrm{w}}$ and color was observed (Table 1 ). Since ${ }^{\circ} \mathrm{Bx}$ and $\% \mathrm{M}$ are related to $\mathrm{a}_{\mathrm{w}}$, their variations could explain the wide range of values observed in this parameter, which is related to variations in shelf life. Montañez-Soto et al. (2013) obtained higher $\mathrm{a}_{\mathrm{w}}$ average value in agave syrups prepared under laboratory conditions.

Traditional syrups, with the darkest color, showed the highest values for $\mathrm{L}^{*}(100)$, $\mathrm{a}^{*}(48.01)$, and $\mathrm{b}^{*}(100)$. Darker colors are mainly associated with caramelization reactions induced by high temperatures during the heating process, and in a lower degree by the occurrence of Maillard reactions (Mancilla-Margalli \& López, 2002; White, 2009). It was found a greater variability on $\mathrm{L}^{*}, \mathrm{a}^{*}$ and $\mathrm{b}^{*}$ color parameters than those reported by Willems and Low (2012). Their low variability could be attributed to the fact that they only worked with industrial syrups.

\subsection{Analysis of Variance (ANOVA)}

Results of ANOVA are shown in Tables 2 and 3. According to the state of production (Table 2), pH showed highly significant differences $(\mathrm{p}<0.000)$, being $\mathrm{Q}$ the state with the highest value. 5-HMF also shown highly significant differences $(\mathrm{p}<0.000)$, being $\mathrm{C}$ the state with the highest content. Regarding color, a* was the only parameter that showed significant differences $(\mathrm{p}<0.05)$, being $\mathrm{N}$ the state with the most noticeable difference in color. A change on the sign of the axis for this parameter $\left(-\mathrm{a}^{*}\right.$, green) was observed, respect to the other regions which were $\left(+\mathrm{a}^{*}, \mathrm{red}\right)$, meaning differences on the tone of color of the samples. $-\mathrm{a}^{*}$ suggests less production of caramelization pigments.

Table 2. ANOVA and Fisher's LSD Test Results According to the State of Production.

\begin{tabular}{|c|c|c|c|c|c|c|c|}
\hline \multirow[t]{2}{*}{ Parameter $^{\$}$} & \multirow[t]{2}{*}{ p-Value ${ }^{\#}$} & \multicolumn{6}{|c|}{ State $^{\&}$} \\
\hline & & $\mathrm{C}$ & E & $\mathrm{H}$ & $\mathrm{J}$ & $\mathrm{N}$ & $\mathrm{Q}$ \\
\hline RI & 0.621 & $1.474^{\mathrm{ab}}$ & $1.480^{\mathrm{b}}$ & $1.481^{\mathrm{ab}}$ & $1.478^{\mathrm{ab}}$ & $1.478^{\mathrm{ab}}$ & $1.476^{\mathrm{a}}$ \\
\hline${ }^{\circ} \mathrm{Bx}$ & 0.078 & $73.50^{\mathrm{ab}}$ & $75.45^{\mathrm{b}}$ & $75.60^{\mathrm{ab}}$ & $74.62^{\mathrm{ab}}$ & $75.10^{\mathrm{a}}$ & $73.84^{\mathrm{a}}$ \\
\hline$a_{w}$ & 0.229 & $0.706^{\mathrm{bc}}$ & $0.640^{\mathrm{a}}$ & $0.628^{\mathrm{ab}}$ & $0.650^{\mathrm{ab}}$ & $0.639^{\mathrm{abc}}$ & $0.693^{c}$ \\
\hline $\mathrm{pH}$ & $0.000 * * *$ & $3.56^{\mathrm{b}}$ & $4.42^{\mathrm{a}}$ & $4.40^{\mathrm{abc}}$ & $4.44^{\mathrm{a}}$ & $4.27^{\mathrm{abc}}$ & $5.00^{\mathrm{c}}$ \\
\hline$\% \mathrm{M}$ & 0.654 & $25.00^{\mathrm{a}}$ & $42.73^{\mathrm{a}}$ & $22.40^{\mathrm{a}}$ & $23.30^{\mathrm{a}}$ & $23.40^{\mathrm{a}}$ & $23.70^{\mathrm{a}}$ \\
\hline$\%$ Ash & 0.194 & $0.127^{\mathrm{b}}$ & $0.108^{\mathrm{a}}$ & $0.100^{\mathrm{a}}$ & $0.115^{\mathrm{ab}}$ & $0.100^{\mathrm{a}}$ & $0.108^{\mathrm{a}}$ \\
\hline 5-HMF & $\mathbf{0 . 0 0 0} * * *$ & $0.113^{\mathrm{c}}$ & $0.018^{\mathrm{ab}}$ & $0.005^{\mathrm{ab}}$ & $0.017^{\mathrm{b}}$ & $0.013^{\mathrm{ab}}$ & $0.004^{\mathrm{a}}$ \\
\hline $\mathrm{L}^{*}$ & 0.180 & $3.29^{\mathrm{b}}$ & $79.39^{\mathrm{a}}$ & $58.62^{\mathrm{ac}}$ & $67.61^{\mathrm{a}}$ & $94.66^{\mathrm{a}}$ & $43.19^{\mathrm{bc}}$ \\
\hline$a^{*}$ & $0.001 * * *$ & $16.79^{\mathrm{ab}}$ & $10.45^{\mathrm{a}}$ & $23.85^{\mathrm{ab}}$ & $11.57^{\mathrm{a}}$ & $-2.26^{\mathrm{a}}$ & $34.08^{\mathrm{b}}$ \\
\hline$b^{*}$ & 0.064 & $5.46^{\mathrm{b}}$ & $62.40^{\mathrm{a}}$ & $72.33^{\mathrm{a}}$ & $50.22^{\mathrm{a}}$ & $35.08^{\mathrm{ab}}$ & $64.81^{\mathrm{a}}$ \\
\hline
\end{tabular}

\$ RI: Refractive Index; aw: Water activity, 5-HMF: 5-(hydroxymethyl)furfural (g/100 g)

\# Significant at $* \mathrm{p}<0.05, * * \mathrm{p}<0.01, * * * \mathrm{p}<0.001$ 
\& J= Jalisco, H=Hidalgo, $\mathrm{C}=$ Coahuila, E=Estado de México, Q= Querétaro, N=Nuevo León

a-c Values are the mean of three replicates of 25 samples. Means without a common letter in rows indicates statistical differences by LSD $\mathrm{p}<0.05$.

According to the production process (Table 3), significant differences $(\mathrm{p}<0.05)$ were observed for $\mathrm{RI},{ }^{\circ} \mathrm{Bx}, \mathrm{a}_{\mathrm{w}}$, $\mathrm{pH}$ and $\mathrm{b}^{*}$. Samples of A process had the highest significant values $\mathrm{a}_{\mathrm{w}}$ and $\mathrm{pH}$, and on the contrary, $\mathrm{RI},{ }^{\circ} \mathrm{Bx}$, and $\mathrm{b}^{*}$ had the lowest ones. Those differences could be associated with the lower content of sugars in A samples. On the other hand, I and S samples did not show significant differences between their quality parameters.

Table 3. ANOVA and Fisher's LSD Test Results According to the Production Process

\begin{tabular}{lllll}
\hline Parameter $^{\%}$ & $\mathrm{p}-$ Value $^{\#}$ & \multicolumn{3}{l}{ Production process } \\
\cline { 3 - 5 } & & $\mathrm{A}$ & $\mathrm{I}$ & $\mathrm{S}$ \\
\hline $\mathrm{RI}$ & $\mathbf{0 . 0 3 2}^{*}$ & $1.472^{\mathrm{b}}$ & $1.479^{\mathrm{a}}$ & $1.478^{\mathrm{a}}$ \\
${ }^{\circ} \mathrm{Bx}$ & $\mathbf{0 . 0 0 0}^{* * *}$ & $71.75^{\mathrm{b}}$ & $74.92^{\mathrm{a}}$ & $74.75^{\mathrm{a}}$ \\
$\mathrm{a}_{\mathrm{w}}$ & $\mathbf{0 . 0 0 7}^{* *}$ & $0.740^{\mathrm{a}}$ & $0.651^{\mathrm{b}}$ & $0.646^{\mathrm{b}}$ \\
$\mathrm{pH}$ & $\mathbf{0 . 0 0 0}^{* * *}$ & $5.05^{\mathrm{a}}$ & $4.49^{\mathrm{b}}$ & $4.27^{\mathrm{b}}$ \\
\%M & 1.000 & $24.55^{\mathrm{a}}$ & $28.18^{\mathrm{a}}$ & $23.27^{\mathrm{a}}$ \\
$\%$ Ash & $\mathbf{0 . 0 2 9}^{*}$ & $0.114^{\mathrm{ab}}$ & $0.109^{\mathrm{b}}$ & $0.126^{\mathrm{a}}$ \\
$5-\mathrm{HMF}$ & 0.621 & $0.056^{\mathrm{a}}$ & $0.013^{\mathrm{a}}$ & $0.022^{\mathrm{a}}$ \\
$\mathrm{L}^{*}$ & 0.109 & $7.83^{\mathrm{a}}$ & $69.57^{\mathrm{a}}$ & $57.91^{\mathrm{a}}$ \\
$\mathrm{a}^{*}$ & 0.062 & $26.41^{\mathrm{a}}$ & $13.87^{\mathrm{a}}$ & $23.23^{\mathrm{a}}$ \\
$\mathrm{b}^{*}$ & $\mathbf{0 . 0 1 4}^{*}$ & $13.36^{\mathrm{b}}$ & $57.32^{\mathrm{a}}$ & $59.45^{\mathrm{a}}$ \\
\hline
\end{tabular}

${ }^{\%}$ RI: Refractive Index; $a_{w}$ : Water activity, 5-HMF: 5-hydroxymethyl furfural (g/100 g)

${ }^{\#}$ Significant at $* \mathrm{p}<0.05, * * \mathrm{p}<0.01, * * * \mathrm{p}<0.001$

${ }^{\&} \mathrm{~A}=$ Traditional, $\mathrm{S}=$ Semi-industrial, $\mathrm{I}=$ Industrial

a-b Values are the mean of three replicates. Means without a common letter in rows indicates statistical differences by LSD $\mathrm{p}<0.05$.

\subsection{Correlation Analysis}

Correlations between quality parameters are shown in Table 4. It was observed significant positive $(\mathrm{p}<0.05)$ correlation between RI and ${ }^{\circ} \mathrm{Bx}$. Those parameters are dependent on the content of sugar in the samples: The higher the content of sugars, the greater the ${ }^{\circ} \mathrm{Bx}$ and $\mathrm{RI}$ values. Both RI and ${ }^{\circ} \mathrm{Bx}$ are significant inversely correlated with $\mathrm{a}_{\mathrm{w}}$, which corresponds to the highly bounded state of the water and carbohydrates on samples. RI and ${ }^{\circ} \mathrm{Bx}$ are also positively correlated with color parameters: $\mathrm{L}^{*}$ and $\mathrm{b}^{*}$. It was observed a significant positive correlation between $\mathrm{pH}, \mathrm{a}^{*}$, and $\mathrm{a}_{\mathrm{w}}$, and inversely correlated with $\%$ Ash, 5-HMF, ${ }^{\circ} \mathrm{Bx}$. A significant negative correlation was found between 5-HMF and L*. Being 5-HMF faint yellow colored, as expected, a decrease in the dark color of the samples was observed. The $\mathrm{a}^{*}$ is significant and positive correlated with $\mathrm{b}^{*}$ and negatively with $\mathrm{L}^{*}$.

Table 4. Correlations Between Analyzed Quality Parameters.

\begin{tabular}{|c|c|c|c|c|c|c|c|c|c|}
\hline Variable $^{\#}$ & ${ }^{\circ} \mathrm{Bx}$ & $\mathrm{a}_{\mathrm{w}}$ & $\mathrm{pH}$ & $\% \mathrm{M}$ & $\%$ Ash & 5-HMF & $\mathrm{L}^{*}$ & $a^{*}$ & $\mathrm{~b}^{*}$ \\
\hline IR & $\underline{0.894}$ & $\underline{-0.901}$ & -0.188 & 0.052 & 0.080 & -0.058 & $\underline{0.586}$ & -0.028 & 0.524 \\
\hline${ }^{\circ} \mathrm{Bx}$ & & $\underline{-0.888}$ & $\underline{-0.421}$ & 0.085 & 0.084 & 0.034 & $\underline{0.635}$ & -0.083 & $\underline{0.522}$ \\
\hline$a_{w}$ & & & $\overline{0.322}$ & 0.002 & -0.112 & 0.069 & $\overline{-0.588}$ & 0.146 & $\overline{-0.447}$ \\
\hline $\mathrm{pH}$ & & & & -0.067 & $\underline{-0.289}$ & $\underline{-0.411}$ & -0.215 & $\underline{0.361}$ & 0.058 \\
\hline$\% \mathrm{M}$ & & & & & -0.122 & 0.107 & 0.048 & -0.023 & 0.152 \\
\hline$\%$ Ash & & & & & & $\underline{0.355}$ & -0.106 & 0.007 & -0.250 \\
\hline 5-HMF & & & & & & & $\underline{-0.283}$ & 0.004 & -0.168 \\
\hline $\mathrm{L}^{*}$ & & & & & & & & $\underline{-0.650}$ & 0.209 \\
\hline$a^{*}$ & & & & & & & & & $\underline{0.454}$ \\
\hline
\end{tabular}

${ }^{\#}$ Significant $(\mathrm{p}<0.05)$; RI: Refractive Index; $\mathrm{a}_{\mathrm{w}}$ : Water activity, 5-HMF: 5-hydroximethyl furfural $(\mathrm{g} / 100 \mathrm{~g})$ 


\subsection{Discriminant Analysis}

Forward stepwise analysis for the state of production let to the selection of tree parameters ( $\mathrm{p}$ inclusion 0.05 , $\mathrm{p}$ exclusion 0.05): 5-HMF, $\mathrm{a}^{*}$ and $\mathrm{b}^{*}$. Only $60 \%$ of the samples were correctly classified according to the state of production. Cooman graphics of Mahalanobis distances (Figure 2A) did not classify all the samples according to the state of production. The best discrimination was obtained for C samples (Coahuila) where $100 \%$ were correctly classified followed by J samples (Jalisco) and Q samples (Querétaro) with $83 \%$ and $80 \%$ of correctly classified samples, respectively. On the other hand, none of the samples from E (Estado de México), H (Hidalgo) and N (Nuevo León) were correctly classified. 5-HMF and a* variables selected for the state of production GDA model were also significant on ANOVA.
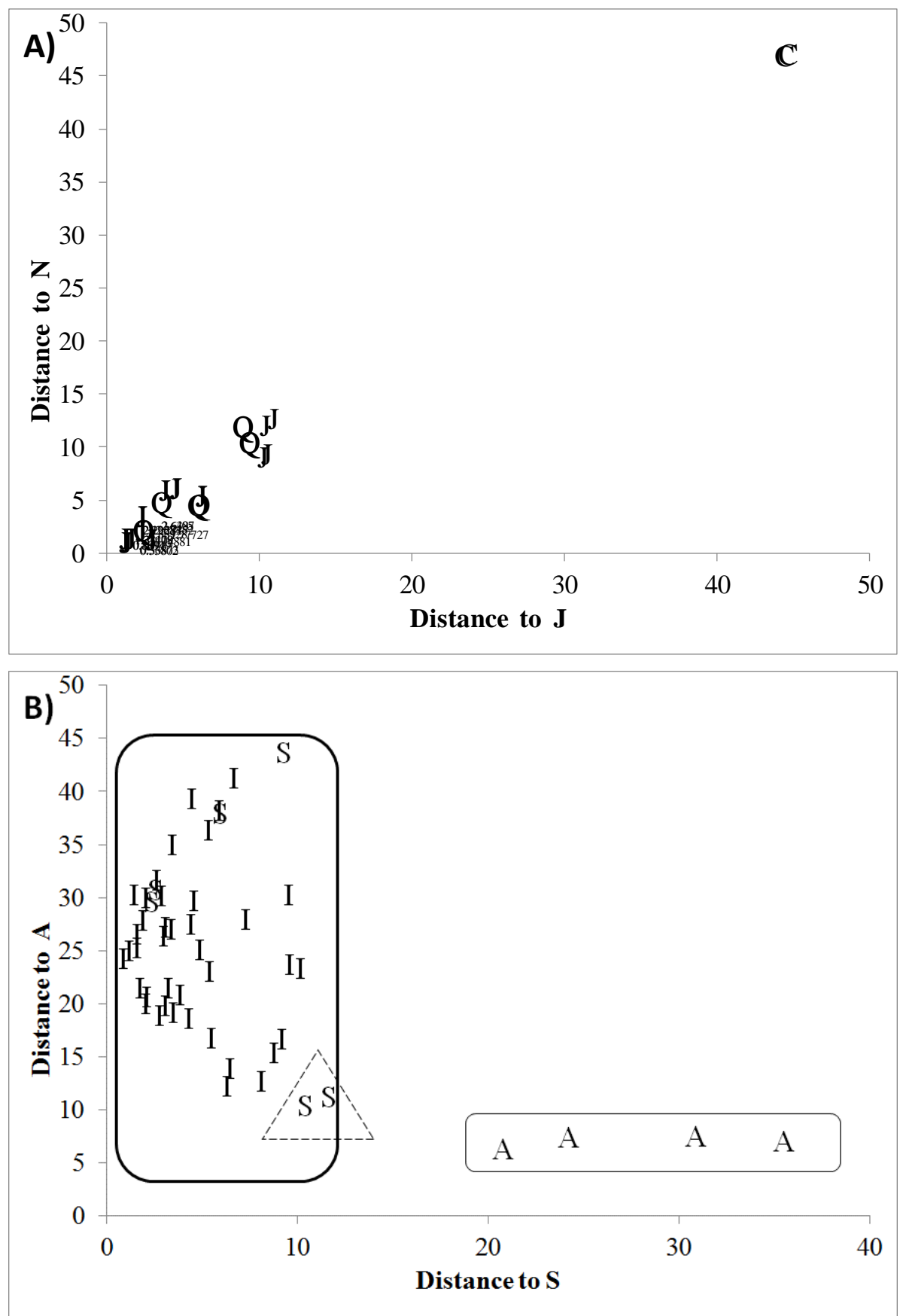

Figure 2. General discriminant analysis (GDA) Cooman's graphs of Mahalanobis distances. A) state of production and $\mathrm{B}$ ) production process. $(\mathrm{J}=$ Jalisco, $\mathrm{H}=$ Hidalgo, $\mathrm{C}=$ Coahuila, $\mathrm{E}=$ Estado de México, $\mathrm{Q}=$ Querétaro). (A= Traditional, $\mathrm{S}=$ Semi-industrial, I= Industrial). 
Forward stepwise analysis for production process let to the selection of five parameters (p inclusion $0.05, \mathrm{p}$ exclusion 0.05$): \mathrm{pH}, \%$ Ash, $\mathrm{b}^{*}, 5-\mathrm{HMF}$ and $\mathrm{a}^{*}$. With the obtained model $92 \%$ of the samples were correctly classified. Misclassification was observed for S (semi-industrial) samples where only 33.33\% were correctly classified (Figure 2B). S misclassified samples were classified as I (industrial), this suggests that these samples were produced with a similar process than industrial ones.

From the variables $\%$ Ash, $\mathrm{pH}$, and $\mathrm{b}^{*}$ were also significant for the ANOVA for the production process. Since $\mathrm{pH}$ and temperature are controlled in the production of semi-industrial agave syrups, and the temperature is related to the production of 5-HMF, it was not surprising that those parameters were selected by the discriminating model.

It was reported that furanic compounds, i.e. 5-HMF are not present on raw agave, there are produced during a cooking process (Prado-Jaramillo, Estarrón-Espinosa, Escalona-Buendía, Cosío-Ramírez, \& Martín-del-Campo, 2015). Lower contents of 5-HMF have been associated with enzymatic hydrolysis of pines (García-Aguirre et al., 2009) that is a regular process of hydrolysis on industrial production. It was not surprising that 5-HMF and some color parameters were selected as discriminant variables because of its formation is highly related with the thermal treatment.

Even when several authors have done studies with agave syrups with different states of production, those studies do not use statistical analysis such as ANOVA or GDA to find out differences among samples (Mellado-Mojica \& López-Pérez, 2013; Willems \& Low, 2012).

\section{Conclusions}

A wide variability of physicochemical quality parameters was observed in the analyzed samples, this variability was confirmed by the ANOVA analysis. GDA made it possible the discrimination between samples according to the production process, but not by the state of production. Traditional control samples were well-discriminated form semi-industrial and industrial ones. Further analysis of samples ensuring the representativeness of each analyzed category, and the inclusion of the analysis of non-regulated compounds such as volatile compounds and carbohydrates are needed to get more specific information that made it possible a deeper characterization of agave syrups.

\section{Acknowledgment}

The authors would like to thank Nekutli S.A. de C.V. and to José Pablo Orozco García from Ingredientes Nutracéuticos de México S.A. de C.V. for providing samples and information for this work.

\section{References}

García-Aguirre, M., Sáenz-Álvaro, V. A., Rodríguez-Soto, M. A., Vicente-Magueyal, F. J., Botello-Álvarez, E., Jimenez-Islas, H., ... Navarrete-Bolaños, J. L. (2009). Strategy for biotechnological process design applied to the enzymatic hydrolysis of agave fructo-oligosaccharides to obtain fructose-rich syrups. Journal of Agricultural and Food Chemistry, 57(21), 10205-10210. https://doi.org/10.1021/jf902855q

García-Pedraza, L. G., Juárez-Flores, B. I., Aguirre-Rivera, J. R., Pinos-Rodríguez, J. M., Martínez, J. F., \& Santoyo, M. E. (2009). Effects of Agave salmiana Otto ex Salm-Dick high-fructose syrup on non-diabetic and streptozotocin-diabetic rats. Journal of Medicinal Plants Research, 3(11), 932-940.

Gutierrez-Uribe, J.-A., \& Serna-Saldivar, S. (2013). USA Patent No. US8,470,858 B2.

Mancilla-Margalli, N. A., \& López, M. G. (2002). Generation of Maillard compounds from inulin during the thermal processing of Agave tequilana Weber Var. Azul. Journal of Agricultural and Food Chemistry, 50(4), 806-812. https://doi.org/10.1021/jf0110295

Mellado-Mojica, E., \& López-Pérez, M. (2013). Comparative analysis between blue agave syrup (Agave tequilana Weber var. Azul) and other natural syrups. Agrociencia (Montecillo), 47(3), 233-244.

Mellado-Mojica, E., \& López, M. G. (2015). Identification, classification, and discrimination of agave syrups from natural sweeteners by infrared spectroscopy and HPAEC-PAD. Food Chemistry, 167, 349-357. https://doi.org/10.1016/j.foodchem.2014.06.111

Montañez-Soto, J. L., González-Hernández, L. H., Venegas-González, J., Bernardino Nicanor, A., \& González-Cruz, L. (2013). Effect of the fructose and glucose concentration on the rheological behavior of high fructose syrups. African Journal of Biotechnology, 12(12), 1401-1407.

https://doi.org/10.5897/AJB12.1936

Montañez Soto, J. L., Venegas González, J., Bernardino Nicanor, A., \& Ramos Ramírez, E. G. (2011). Enzymatic 
production of high fructose syrup from Agave tequilana fructans and its physicochemical characterization. African Journal of Biotechnology, 10(82), 19137-19143. https://doi.org/10.5897/AJB12.1936

Muñiz-Márquez, D. B., Contreras, J. C., Rodríguez, R., Mussatto, S. I., Wong-Paz, J. E., Teixeira, J. A., \& Aguilar, C. N. (2015). Influence of thermal effect on sugars composition of Mexican Agave syrup. CyTA-Journal of Food, 13(4), 607-612. https://doi.org/10.1080/19476337.2015.1028452

NOM-003-SAGARPA-2016. (2016). Relativa a las características de sanidad, calidad agroalimentaria, autenticidad, etiquetado y evaluación de la conformidad del jarabe de agave. In (pp. 29): Diario Oficial de la Federación.

Pardo, O. (2007). The agave (Agave americana L.) in prehispanical cultures: a bibliographical revision. Chloris Chilensis, Revista Chilena de Flora y Vegetación, 10(1). Retrieved from http://www.chlorischile.cl/pardoagave2/Agaveamericana2007.htm

Prado-Jaramillo, N., Estarrón-Espinosa, M., Escalona-Buendía, H., Cosío-Ramírez, R., \& Martín-del-Campo, S. T. (2015). Volatile compounds generation during different stages of the Tequila production process. A preliminary study. LWT - Food Science and Technology, 6, 471-483. https://doi.org/10.1016/j.lwt.2014.11.042

Rendón-Salcido, L. A., Magdub-Méndez, A., Hernández-Terrones, L., \& Larqué-Saavedra, A. (2007). El jarabe de henequén (Agave fourcroydes Lem.). Revista Fitotecnia Mexicana, 30(4), 463-467.

Santos-Zea, L., Maria Leal-Diaz, A., Cortes-Ceballos, E., \& Alejandra Gutierrez-Uribe, J. (2012). Agave (Agave spp.) and Its Traditional Products as a Source of Bioactive Compounds. Current Bioactive Compounds, 8(3), 218-231. https://doi.org/10.2174/157340712802762410

White, J. S. (2009). Misconceptions about high-fructose corn syrup: is it uniquely responsible for obesity, reactive dicarbonyl compounds, and advanced glycation endproducts? The Journal of nutrition, 139(6), 1219S-1227S.

Willems, J. L., \& Low, N. H. (2012). Major Carbohydrate, Polyol, and Oligosaccharide Profiles of Agave Syrup. Application of this Data to Authenticity Analysis. Journal of Agricultural and Food Chemistry, 60(35), 8745-8754. https://doi.org/10.1021/jf3027342

\section{Copyrights}

Copyright for this article is retained by the author(s), with first publication rights granted to the journal.

This is an open-access article distributed under the terms and conditions of the Creative Commons Attribution license (http://creativecommons.org/licenses/by/4.0/). 